\title{
Infective endocarditis, rheumatoid factor, and anticardiolipin antibodies
}

Ronald A Asherson, Mohammed Tikly, Henrique Staub, Peter T Wilmshurst, D John Coltart, Munther Khamashta, Graham R V Hughes

\begin{abstract}
Serum samples from 22 patients with infective endocarditis were analysed for the presence of antibodies to cardiolipin, false positive Venereal Disease Research Laboratory (VDRL) test, and rheumatoid factor in order to determine the prevalence of anticardiolipin antibodies, their level, and to ascertain whether there was any correlation with the presence of rheumatoid factor. Although the latex test was positive in $10 / 22(45 \%)$ patients, anticardiolipin antibodies, usually of a low level, were raised in only four (18\%), and the VDRL test was positive in two patients in whom other antibodies were negative. These results show a clear discordance between these three tests, indicating that $B$ cell production of these antibodies is separate and distinct. As with other infections which result in anticardiolipin antibody production, no thrombotic events were encountered.
\end{abstract}

In a recent study reported in this journal ${ }^{1}$ we encountered a problem in two patients with systemic lupus erythematosus, valve lesions, and increased anticardiolipin antibodies, in whom the diagnosis of superimposed infective endocarditis was suspected. Because of significant increases of the anticardiolipin antibodies in both, the question as to whether infective endocarditis could be associated with these increases arose. We have attempted to answer this question by analysing a group of patients with infective endocarditis for the presence of these antibodies. We also analysed the sera for rheumatoid factor to ascertain whether there was any correlation between its presence and the demonstration of anticardiolipin antibodies.

The Lupus Arthr

The Rayne Institute

St Thomas's Hospital, London SE1 7EH

R A Asherson

H Staub

M Khamashta

G R V Hughes

Department of

Cardiology,

St Thomas's Hospital,

London SE1 7EH

P T Wilmshurst

D J Coltart

Department of Medicine, University of the Witwatersrand,

The Baragwanath

Hospital, Johannesburg,

South Africa

M Tikly

Correspondence to:

Dr Asherson.

Accepted for publication

18 May 1989

\section{Materials and methods}

Serum samples were collected from 12 patients with infective endocarditis, who had presented at the Baragwanath Hospital, Johannesburg, South Africa, and from a further 10 patients attending St Thomas's Hospital, London, United from infective endocarditis because of (a) clinical features suggestive of infective endocarditis; (b) positive blood cultures; (c) echocardiographic features in keeping with 'vegetations'; and (d) vegetations seen during surgery. All serum samples were collected within 48 hours of admission to hospital. Patients had been ill for up to four weeks before collection of serum samples and before treatment was started.

Antibodies to cardiolipin were detected by an enzyme linked immunosorbent assay (ELISA) as described by Gharavi et $a l^{2}$; IgG and IgM isotypes were determined. The Venereal Disease Research Laboratory (VDRL) test, Treponema pallidum haemagglutination test, and latex test for rheumatoid factors were performed according to standard techniques. ${ }^{34}$ The lupus 'anticoagulant' was not measured routinely as this test requires plasma and these analyses were performed on stored serum samples.

\section{Results}

Ten patients were completely negative for all immunological tests performed, while 12 showed positivity in one or another test. The table shows the results for these 12 patients. Patients with raised anticardiolipin antibody levels were culture positive (Streptococcus viridans (two), Escherichia coli (one)). The fourth patient (No 11) developed a candida endocarditis on a prosthetic valve replacement.

The VDRL test was positive in two patients only (1/4), but the latex test for rheumatoid factor was positive in 10 of the 22 patients. Anticardiolipin antibodies were positive in four-a low level of IgM anticardiolipin antibodies in three (accompanied by moderate increases of IgG anticardiolipin antibodies in one) and a moderate increase of IgG anticardiolipin antibodies in one. There was no association between increased antibodies and the false positive VDRL test present in the two patients. The prevalence of positive anticardiolipin antibodies in this group of patients with infective endocarditis was $18 \%$, consisting of low levels of IgM anticardiolipin antibodies $(13 \%)$ and moderate increases in IgG anticardiolipin antibodies $(9 \%)$. Kingdom. Patients were deemed to be suffering
Serological features of the 12 patients with seropositive infective endocarditis

\begin{tabular}{lllll}
\hline $\begin{array}{l}\text { Patient } \\
\text { No }\end{array}$ & $\begin{array}{l}R A^{*} \\
\text { latex } \\
\text { test }\end{array}$ & $\begin{array}{l}\text { VDRL } \\
\text { test }\end{array}$ & $\begin{array}{l}\text { IgG aCL* } \\
\text { antibodies }\end{array}$ & $\begin{array}{l}\text { IgM aCL } \\
\text { antibodies }\end{array}$ \\
\hline 1 & - & + & - & - \\
2 & + & + & - & - \\
3 & + & - & - & - \\
4 & + & - & - & Low \\
5 & + & - & Mod & Low \\
6 & + & - & - & - \\
7 & + & - & - & Low \\
8 & + & - & - & - \\
9 & + & - & - & - \\
10 & + & - & Mod & - \\
11 & + & - & - & \\
12 & + & & &
\end{tabular}

${ }^{*}$ RA = rheumatoid arthritis; VDRL = Venereal Disease Research Laboratory; $\mathrm{aCL}=$ anticardiolipin. 


\section{Discussion}

The spectrum of valvular heart disease in systemic lupus erythematosus has undergone major and significant changes over the past few years. This is due both to an increased awareness of the clinicians and the improved methods of detection available today. . $^{58}$ The LibmanSacks type of endocarditis ${ }^{9}$ as originally described is still often encountered at necropsy and is haemodynamically insignificant. Significant valve lesions, predominantly regurgitant, have been reported increasingly often, some requiring valve replacement. ${ }^{10-12}$

The problem of infection superimposed on damaged valves with resultant bacterial endocarditis has been well reviewed by Lehman et $a l^{13}$ and others. ${ }^{14} \mathrm{~A}$ variety of infections have been associated with increases of anticardiolipin antibodies, including infectious mononucleosis and AIDS. ${ }^{15} 16$

The not infrequent association of false positive VDRL tests with antiphospholipid antibodies, ${ }^{17}$ the well known occurrence of false positive VDRL tests as well as rheumatic complaints and rheumatoid factors in patients with infective endocarditis, ${ }^{18-22}$ and the recent problem we had encountered ${ }^{1}$ all prompted us to undertake this limited study. Rheumatoid factor was present in 10 of $22(45 \%)$ patients studied.

High levels of anticardiolipin antibodies were not encountered in this study and therefore any large increases of these antibodies found in patients with valve lesions and systemic lupus erythematosus may be attributed to the underlying lupus process itself and not to the endocarditis.

1 Asherson R A, Gibson D G, Evans D W, Baguley E, Hughes $G R$ V. Diagnostic and therapeutic problems in two patients with antiphospholipid antibodies, heart valve lesions and transient ischaemic attacks. Ann Rheum Dis 1988; 47: 947-53.

2 Gharavi A E, Harris E N, Asherson R A, Hughes G R V. Anticardiolipin antibodies: isotype distribution and phospholipid specificity. Ann Rheum Dis 1987; 46: 1-6.
3 Nelson R A, Mayer M M. Immobilization of Treponema pallidum in vitro by antibody produced in syphilitic infection. $\mathcal{f}$ Exp Med 1949; 89: 369.

4 Harris A, Colman M B, eds. Diagnostic procedures and reagents. 4th ed. New York: American Health Association, reagen
1963.

5 Klinkhoff A V, Thompson C R, Reid G D, Tomlinson C W. $M$-mode and two-dimensional echocardiographic abnormalities in systemic lupus erythematosus. FAMA 1985; 253: 3273-7.

6 Kahan A, Amor B, de Vernejoul F, Saporta L. Libman Sacks endocarditis: the diagnostic importance of two dimensional echocardiography. Brf Rheumatol 1985; 24: 187-90.

7 Galve E, Candell-Riera J, Pigrau C, Permanyer-Miralda G, Garcia Del-Castello H, Soler-Soler J. Prevalence, morphological types in evolution of cardiac valvular disease in systemic lupus erythematosus. $N$ Engl 7 Med 1988; 319: 817-23.

8 Straaton K V, Chatham W W, Reveille J D, et al. Clinically significant valvular heart disease in systemic lupus erythematosus. Am F Med 1988; 85: 645-50.

9 Libman E, Sacks B. A hitherto undescribed form of valvular and mural endocarditis. Arch Intern Med 1924; 33: 701-37.

10 Rawsthorne L, Ptacin M J, Choi H, Ollinger G N, Bamrah B S. Lupus valvulitis necessitating double valve replaceB S. Lupus valvulitis necessitating do

11 Paget S A, Bulkley B H, Grauer L E, Seningen R. Mitra valve disease of systemic lupus erythematosus. Am $\mathcal{F}$ Med 1975; 59: 134-9.

12 Vaughton K C, Walker D R, Sturridge M F. Mitral valve replacement for mitral stenosis caused by Libman Sacks endocarditis. Br Heart $\mathcal{F}$ 1979; 41: 730-3.

13 Lehman T J A, Palmeri S T, Hastings C, Klippel J H, Plotz P H. Bacterial endocarditis complicating systemic lupus erythematosus. I Rheumatol 1983; 10: 655-8.

14 Tornos M P, Galve E, Pahissa A. Clinical considerations regarding Libman Sacks endocarditis. Int f Cardiol 1985; 7: 409-12.

15 Vaarala O, Palosko T, Kleemola M, Aho K. Anticardiolipin response in acute infections. Clin Immunol Immunopathol response in acuic

16 Canoso R T, Zon L I, Groopman J E. Anticardiolipin antibodies associated with HTLV-III infection. $\mathrm{Br} f$ Haematol 1987; 65: 495-8.

17 Harris E N, Gharavi A E, Wasley G D, Hughes G R V. Use of an enzyme linked immunosorbent assay and of inhibition studies to distinguish between antibodies to cardiolipin from patients with syphilis or autoimmune disorders. F Infect $D$ is 1988; 157: 23-31.

18 Messner R P, Laxdal T, Quie P G, Williams R C. Rheumatic factor in subacute bacterial endocarditis-Bacterium duration of disease or genetic predisposition? Ann Intern Med 1968; 68: 746-56.

19 Azevedo J, Ribeiro C, Loureiro O, Cordeiro A. Rheumatic symptoms and signs in subacute infective endocarditis. Eur symptoms and signs in subacute

20 Thomas Ph, Allal J, Bontoux D, et al. Rheumatological manifestations of infective endocarditis. Ann Rheum D 1984; 43: 716-20.

21 Roberts-Thomson P J. Serological investigations in the diagnosis and management of infective endocarditis. Aus NZF Med 1986; 16: 761-5.

22 Koh L Y, Johns D N, Roberts-Thomson P J. Appearance of low molecular weight IgM during course of infective endocarditis. Clin Exp Immunol 1986; 64: 471-5. 